\title{
JOINT SYMPTOMS IN MYELOMATOSIS AND SIMILAR CONDITIONS*
}

\author{
BY \\ E. B. D. HAMILTON AND E. G. L. BYWATERS \\ From the M.R.C. Rheumatism Research Unit, Canadian Red Cross Memorial Hospital, \\ Taplow, Maidenhead, Berks., and the Department of Medicine, Post-Graduate Medical School of London
}

The commonest presenting symptom in myelomatosis is pain in the back, which is frequently associated with vertebral collapse. Subsequently the patient may complain of sciatica or brachial neuralgia due to nerve root pressure. This may be a direct result of the collapse, or in some cases may be caused by an extradural plaque of myeloma cells. A less common but well-recognized presentation is a polyarthritis, which superficially resembles rheumatoid arthritis and is usually treated as such in the first instance. 24 cases of this type have now been reported in the literature; among the most important reports are those of Magnus-Levy (1938), Stewart and Weber (1938), Tarr and Ferris (1939), and Davis, Weber, and Bartfeld (1957). Such a patient is middle-aged and develops an arthritis which may or may not be painful. The pattern of joint involvement is variable, but the small joints of the hands frequently become swollen. A careful examination may reveal the presence of nodules in the neighbourhood of joints, attached to bony prominences, or in skeletal muscle, and in two of the thirteen cases reviewed by Tarr and Ferris there was macroglossia. Biopsy or autopsy examination of affected joints or of nodules will show infiltration with para-amyloid. This apparent arthritis frequently precedes any overt manifestations of myelomatosis, but it can develop during the course of the disease. It should not be confused with pain seeming to arise in joints from myelomatous involvement of adjacent bone, which is not uncommon in the hips and shoulders.

Recently we have seen several patients with arthritis who on subsequent investigation have been found to have myelomatosis, and the purpose of this paper is to review these cases against a background of all cases of myelomatosis seen at the

* Read at a meeting of the Heberden Society on December 1, 1961.
Hammersmith Hospital, and at the Canadian Red Cross Memorial Hospital, Taplow, during the past 10 years. Six other relevant cases are also reported: two of rheumatoid arthritis and macroglobulinaemia, two with a myeloma-like protein in the peripheral blood but no other manifestations of myelomatosis, and two with primary amyloidosis.

The 46 cases of myelomatosis included in this survey were seen during the 10-year period from January, 1950, to January, 1960; in all cases the diagnosis had been unequivocally confirmed by sternal marrow examination, tumour biopsy, or at autopsy. The clinical features present in the 46 cases are summarized in Table $\mathbf{I}$.

TABLE I

CLINICAL AND LABORATORY DATA IN 46 CASES OF MYELOMATOSIS

\begin{tabular}{|c|c|c|}
\hline Total Number of Cases & 46 & Percentage \\
\hline Male : Female Ratio .. & $26: 20$ & \\
\hline Average Age at Onset (yrs) (range 35-75) & 57 & \\
\hline $\begin{array}{l}\text { No. Alive at End of Study } \\
\text { Mean Duration to Last } \\
\text { Follow-up (yrs) } \\
\text { (range } 6 \text { wks to } 9 \text { yrs) } \\
\end{array}$ & 22 & 48 \\
\hline $\begin{array}{l}\text { No. Died (Post mortem Examination } \\
\text { Taplow 4, Hammersmith 15) } \\
\text { Mean Duration of Life (yrs) (range 2/12-7) } \ldots\end{array}$ & $\begin{array}{c}24 \\
2 \cdot 2\end{array}$ & 52 \\
\hline Bone Pain & $42 / 46$ & 91 \\
\hline $\begin{array}{l}\text { Raised Erythrocyte Sedi- } \\
\text { mentation Rate (mm./hr, } \\
\text { Westergren) }\end{array}$ & $\begin{array}{r}4 / 30 \\
10 / 30 \\
16 / 30\end{array}$ & $\begin{array}{l}13 \\
33 \\
54\end{array}$ \\
\hline Myeloma Peak on Electrophoresis .. & $25 / 34$ & 73 \\
\hline Bence Jones Proteose .. & $18 / 44$ & 41 \\
\hline Proteinuria & $22 / 44$ & 50 \\
\hline Osteolytic Lesions on $X$ Ray & $39 / 45$ & 87 \\
\hline Hypercalcaemia $12 \mathrm{mg}$. per cent. or More ... & $10 / 25$ & 40 \\
\hline Alkaline Phosphatase 15 K.A. Units or More & $3 / 25$ & 12 \\
\hline
\end{tabular}


Of these patients 24 have died and the autopsies performed in nineteen of them confirmed the diagnosis. The mean duration to death was $2 \cdot 2$ years (range 2 months to 7 years), and this compares with a mean duration to last follow-up in the other 22 cases of $2 \cdot 4$ years (range 6 weeks to 9 years). One of the most prominent symptoms was bone pain, and this was present at some stage of the disease in 42 (91 per cent.) of the cases.

Laboratory investigations revealed erythrocyte sedimentation rates of $101 \mathrm{~mm}$. or over in 1 hour in 54 per cent. of thirty cases examined, and in 33 per cent. the rate lay between 51 and $100 \mathrm{~mm}$. Examination of the plasma proteins showed a reversed albumin/globulin ratio in 70 per cent. In 34 cases in which electrophoresis was performed, 73 per cent. showed a distinct myeloma peak in the beta- or gamma-globulin region. Bence Jones proteose was detected in the urine in 41 per cent. of cases at some stage in the disease.

Radiological examination showed the presence of definite osteolytic lesions in 87 per cent. Hypercalcaemia of $12 \mathrm{mg} . / 100 \mathrm{ml}$. or more was present in 40 per cent. of 25 cases, but in only 12 per cent. of these was the alkaline phosphatase raised above 15 King-Armstrong units.

The musculo-skeletal manifestations seen in these 46 cases are shown in Table II. Bone pain was usually felt in the lumbar or dorsal spine, often associated with vertebral collapse, but in eight cases the patient specifically complained of severe pain referred to the joints. This pain was felt in one or both hip joints in six cases, and in the shoulder joint in the remaining two cases. One of these cases has been reported below because pain in the hip was the presenting feature, but in the remainder the pain occurred during the course of the disease and did not give rise to any diagnostic problem. Radiology revealed osteolytic lesions in

TABLE II

MUSCULO-SKELETAL MANIFESTATIONS

\begin{tabular}{|c|c|c|c|c|c|c|c|}
\hline \multicolumn{2}{|c|}{ Total Number of Cases } & . & . & . & . & $\cdots$ & \multirow{2}{*}{$\begin{array}{r}46 \\
8 \\
34 \\
4\end{array}$} \\
\hline Bone Pain & \multicolumn{4}{|c|}{$\begin{array}{l}\text { Simulating joint disease } \\
\text { Not simulating joint disease }\end{array}$} & $\begin{array}{l}\cdots \\
\cdots \\
\cdots\end{array}$ & & \\
\hline $\begin{array}{l}\text { Joint and } \\
\text { Tendon } \\
\text { Disease }\end{array}$ & \multicolumn{6}{|c|}{ 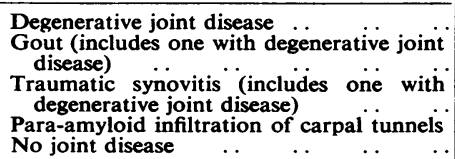 } & $\begin{array}{r}2 \\
1 \\
40\end{array}$ \\
\hline \multicolumn{2}{|c|}{$\begin{array}{l}\text { "Brachial neuralgia" } \\
\text { Sciatica }\end{array}$} & $\begin{array}{l}\cdots \\
\cdots\end{array}$ & $\begin{array}{l}\cdots \\
\cdots\end{array}$ & $\begin{array}{l}\cdots \\
\cdots\end{array}$ & $\begin{array}{l}\cdots \\
\cdots\end{array}$ & & $\begin{array}{l}4 \\
7\end{array}$ \\
\hline
\end{tabular}

the neighbourhoood of the joints, but in none was there collapse of the femoral head. In all these cases it was found necessary to give deep $x$-ray therapy to the region of the joint for relief of pain.

Case 1, a 60-year-old electrician, was admitted to Hammersmith Hospital for radiotherapy in December, 1952. At the beginning of 1949 , he had started to have treatment at another hospital for osteo-arthritis of the hips, and in March of that year he sustained a subtrochanteric fracture of his left femur through a cystic area of bone after trivial trauma. This was biopsied but showed no tumour tissue and he had been discharged wearing a caliper. In January, 1950, he began to complain of severe backache and $\boldsymbol{x}$ rays showed destruction of the laminae and spine of the second lumbar vertebra. He was treated with radiotherapy and subsequently had further courses, together with urethane before he died of renal failure in January, 1956.

Autopsy (Prof. C. V. Harrison) confirmed the diagnosis of myelomatosis and there were bilateral myeloma kidneys.

Bone pain seeming to arise from joints has to be distinguished from sciatica and "brachial neuralgia", which was present in seven and four cases respectively.

Diseases of the joints or tendon sheaths were present in six of the 46 cases (Table II). Only one case of para-amyloid infiltration, of the type alread described, was found (Case 2); this patient had marked infiltration of both carpal tunnels 6 years after the onset of disease, and the symptoms were dramatically relieved by bilateral decompression.

There were three patients with degenerative joint disease, and two of them came under the care of the Rheumatology Unit because of their arthrosis. In these two patients it was the presence of an abnormally high erythrocyte sedimentation rate which led to the discovery of the underlying myelomatosis. A good example of this group of patients is Case 3 (described below), who showed no radiological evidence of myelomatosis for 21 months after the myeloma protein had been detected in the blood. Occult or symptomless myelomatosis has previously been reported by Osserman (1958) and by Baker and Martin (1959). Two further cases of possible occult myeloma will be described later, but as they are still under observation 3 years after the discovery of the myeloma-like protein in the peripheral blood, they cannot be included with those cases in whom the diagnosis is proven.

Acute attacks of gout occurred in two patients, one of whom also had degenerative joint disease (Case 3) and the serum uric acid rose to $16.5 \mathrm{mg}$. per cent. before she died. When the uric acid estimation was made, the blood urea level was $48 \mathrm{mg} . / 100 \mathrm{ml}$. There were also two cases of 
traumatic synovitis of the knee joint, but they did not present any unusual features.

Case 2, a 36-year-old woman, was first admitted to the Hammersmith Hospital in 1955 with a one-year history of low back pain. Radiography revealed vertebral collapse, and biopsy of the affected vertebra showed myeloma tissue. The symptoms improved with deep $x$-ray therapy, but further osteolytic lesions appeared in succeeding years requiring repeated courses of treatment. Bence Jones proteose was detected in 1958 and at that time the plasma proteins were $6 \cdot 8 \mathrm{~g}$. per cent. with no myeloma peak present on electrophoresis. In October, 1959, she complained of pain and stiffness in both shoulders, which was associated with humeral deposits.

Paraesthesiae in the median nerve distribution in both hands was first noticed in January, 1960 . This gradually became more intense and was very severe during the night. During 1960 she lost 2 stone in weight and in September was re-admitted to hospital. There was marked swelling of both carpal tunnels (Fig. 1), wasting of the thenar eminences, and hypoaesthesia in the median nerve distributions. There were bilateral frozen shoulders, slight limitation of full extension of the right elbow, and a small effusion in the right knee joint. Reddish-brown cutaneous deposits were present in the upper eyelids (Fig. 2) and around the anus.

Laboratory investigations showed plasma proteins of $6.8 \mathrm{~g}$. per cent., and electrophoresis showed a marked rise in the alpha-2 and beta globulins. The sternal marrow contained 20 per cent. plasma cells, many of which were immature. Serum calcium was $6.8 \mathrm{mEq} / \mathrm{l}$., inorganic phosphate $2 \mathrm{mEq} / \mathrm{l}$, alkaline phosphatase $7 \mathrm{~K}$.A. units, serum uric acid $6 \cdot 1 \mathrm{mg}$. per cent., and the blood urea $63 \mathrm{mg}$. per cent. A 24-hour urine collection contained $1,300 \mathrm{mg}$. protein $/ 100 \mathrm{ml}$., and the congo red retention was 35 per cent. in 1 hour.

On October 7,1960, a bilateral carpal tunnel decompression was performed with immediate relief of symptoms, and the carpal tunnel was found to be infiltrated with para-amyloid. A biopsy of a perianal cutaneous deposit also showed para-amyloid. She was treated with systemic steroids and blood transfusions and was feeling much better when discharged from hospital on November 24, 1960.

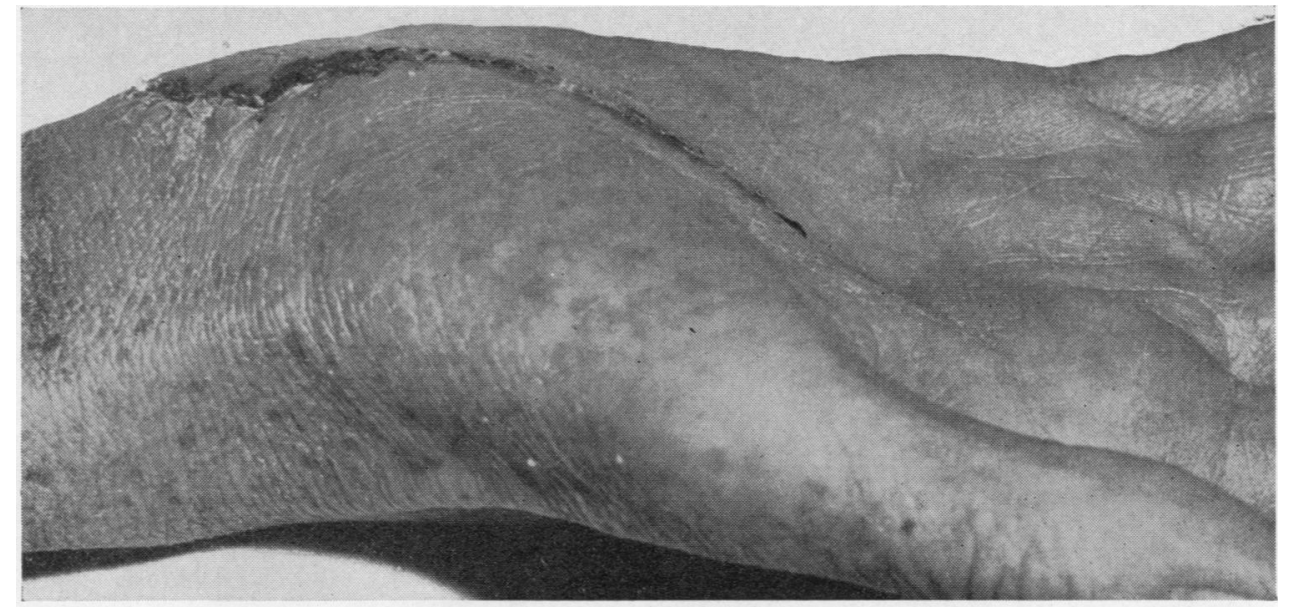

Fig. 1.-Case 2, showing swelling of carpal tunnel.

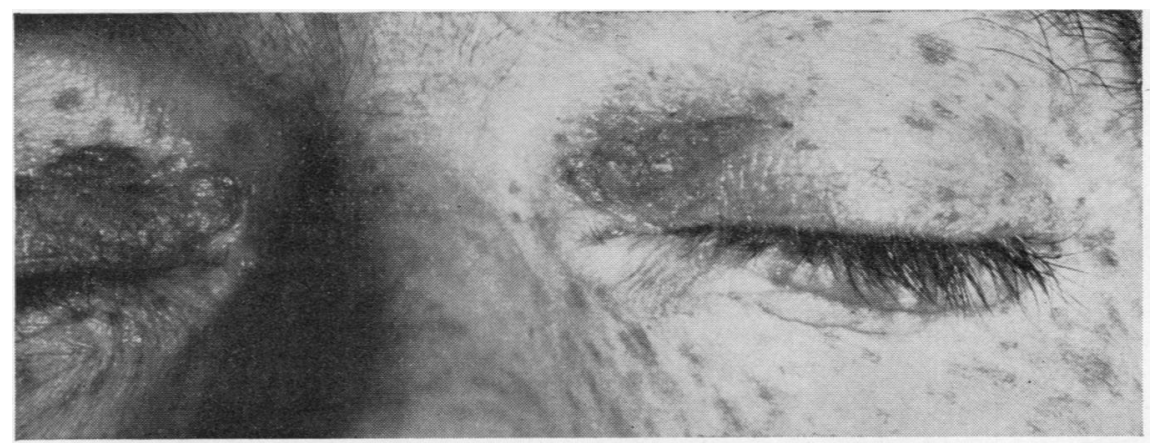

Fig. 2.-Case 2, showing amyloid deposits on upper eyelids. 
Case 3, a 71-year-old widow, was first admitted to Hammersmith Hospital on June 24, 1954, with a 5-year history of pain and swelling of the knees; more recently she had had angina of effort and nocturnal orthopnoea. Examination showed an obese woman in early congestive failure with effusions in both knee joints, limited hip movement, and a blood pressure of $180 / 100$. There was only a trace of albumin in the urine. Laboratory investigations showed an erythrocyte sedimentation rate ranging from 43 to $87 \mathrm{~mm}$. in 1 hour (Westergren), a haemoglobin of $14.3 \mathrm{~g}$. per cent., and a white blood count of 3,600 per c.mm., with a normal differential count. Total proteins were $8 \cdot 5 \mathrm{~g}$. per cent. with an albumin/globulin ratio of $4 \cdot 3: 4 \cdot 2$. Changes of cardiac ischaemia were seen on electrocardiography, and the chest $x$ ray showed cardiac enlargement with pulmonary congestion. The cardiac failure responded to treatment, and the persistently raised sedimentation rate suggested that the arthritis might have been rheumatoid in nature despite a negative Rose-Waaler titre and the absence of erosions.

In 1955 she had a left haemarthrosis following a fall, and in August was re-admitted with severe dyspnoea. There was widespread bronchospasm, but she was not in cardiac failure. The haemoglobin had fallen to $8 \mathrm{~g}$. per cent., and the erythrocyte sedimentation rate was $98 \mathrm{~mm}$. in 1 hour. Electrophoresis of the plasma proteins showed a high narrow gamma globulin peak and a sternal marrow biopsy contained 60 per cent. of plasma cells. There was moderate albuminuria but no Bence Jones proteose was detected. A skeletal survey revealed no osteolytic lesions. It was decided to transfuse her, but not to treat the myelomatosis with antimitotic drugs.

In the ensuing years there were repeated admissions with anaemia and heart failure, and she suffered from recurrent chest infections. Myelomatous deposits were first detected in 1957, and in 1958 she received radiotherapy to the lumbar spine. The serum uric acid was $8.5 \mathrm{mg} . / 100 \mathrm{ml}$. on November 11,1958 , and this had risen to $13.4 \mathrm{mg} . / 100 \mathrm{ml}$. on March 19,1959 , when the blood urea was $48 \mathrm{mg}$. $/ 100 \mathrm{ml}$. On March 23, 1959 , she developed acute gout of the terminal interphalangeal joint of the left index finger. This was incised under local anaesthesia and uric acid crystals were removed. Thereafter she remained on prophylactic colchicine, but the serum uric acid rose to 16.5 per cent. before her death. She died on April 13, 1959, from bronchopneumonia secondary to infection with an antibioticresistant Pyocyaneus organism.

The autopsy (Prof. C. V. Harrison) confirmed the diagnosis of myelomatosis and the histology of the arthritic finger joint showed deposits of urate crystals in the peri-articular tissues. The right kidney and ureter were absent, but the left kidney was macroscopically and histologically normal.

During the past 10 years six patients with protein abnormalities, in whom a definite diagnosis of myelomatosis was not reached, have been seen by the Rheumatology Unit, and these warrant detailed description. They fall into three separate groups.

(1) Two women (Cases 4 and 5) were seen in December, 1957, with a myeloma-like protein in the peripheral blood (Fig. 3, opposite), and have since been followed up; they have not developed overt myelomatosis, but the protein abnormality persists. In both cases the presence of macroglobulins was excluded by ultracentrifugation.

Case 4 had an acute arthritis of both wrist joints $\Rightarrow$ (Fig. 4), which on biopsy showed changes typical of? rheumatoid arthritis (Fig. 5). The nature of the arthritis, which rapidly progressed to fusion of the wrist joints $\overline{-}$ but has not spread to any other joints, made an infective $\overline{\bar{n}}$. arthritis a possibility, especially as she subsequently $\widehat{\Phi}$ developed a meningococcal meningitis, but culture of the joint synovia was negative.

Case 5 was a 70-year-old nun who suffered from $\vec{\circ}$ degenerative arthritis in the hands and cervical spine.She also complained of continual back pain, with general- $\vec{\omega}$ ized osteoporosis on radiological examination, but no localized osteolytic lesions have appeared.

(2) Two patients (Cases 6 and 7) were seen with a chronic erosive polyarthritis and macroglobulinaemia.

In Case 6 macroglobulins were detected on ultra-o centrifugation, and the cryocrit showed 11 per cent. cryoglobulins. The clinical features conformed to those $\vec{\square}$ described by Martin (1960) in his comprehensive review of 41 cases of macroglobulinaemia.

Case 7 had long-standing crippling arthritis and ter- $\frac{3}{0}$ minally developed pericarditis and pancytopenia, and $\subseteq$ died from massive intestinal haemorrhage. Ultra- $\vec{\bullet}$ centrifuge studies were not performed on this case, Sia's test for macroglobulins was positive and no evideneseof myelomatosis was found at autopsy. The election. phoretic pattern of the plasma proteins is seen in Fig: 3 \& (opposite). L.E. cells were present in the peripheral blood and the Rose-Waaler titre was strongly positive, although it has been persistently negative in Case 6 .

(3) Two patients (Cases 8 and 9) were seen with primary amyloidosis.

Case 8 developed myalgia, macroglossia, symptoms of bilateral carpal tunnel compression, and swelling of the knee joint, soon after making a partial recovery from acute tubular necrosis following repeated haemodialysis. It soon became apparent that there was widespreado involvement with para-amyloid and he subsequently died from heart failure. At autopsy the synovia of the knee joints was stained by the congo red the patient had 3 received in an absorption study carried out before death, $\mathrm{O}$ and histological examination confirmed the presence of 5 para-amyloid. Bence Jones proteose and a slight $\frac{7}{8}$ plasmacytosis in the sternal marrow were also seen in this case, but no further features of myelomatosis weren detected during life or at autopsy.

Case 9 presented with symptoms of peripheral neuritis 0 in the hands and feet, and a year later he also died of heart failure, autopsy revealing widespread para-amyloido infiltration.

Case 4, a 49-year-old nurse, was admitted to thees Canadian Red Cross Memorial Hospital, in December, 1957. She had been in good health until 2 weeks before 
CASE 4

TOTAL PROTEIN

$7.9 \mathrm{~g}$.

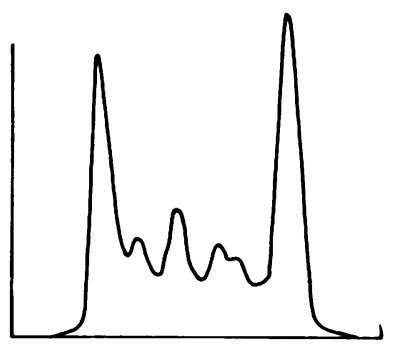

CASE 5

TOTAL PROTEIN

7.1 g.

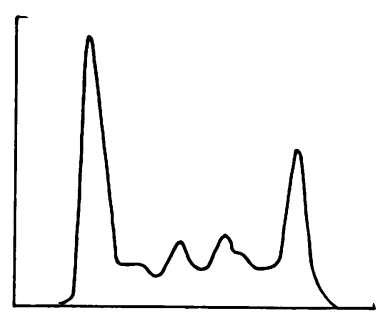

CASE 6

TOTAL PROTEIN

$10.1 \mathrm{~g}$.

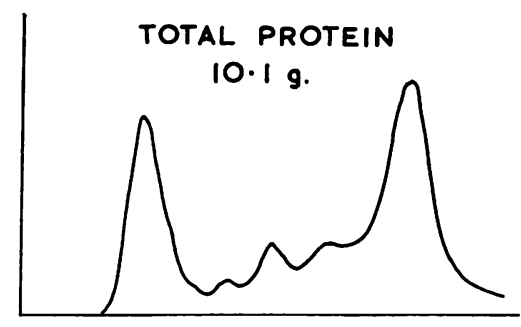

CASE 7

CASE 8

TOTAL PROTEIN

8.1 g.

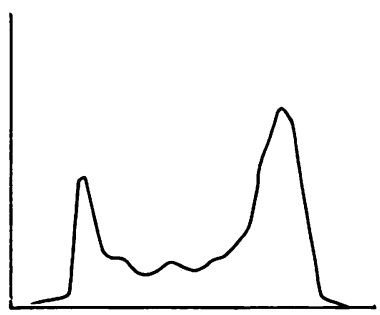

TOTAL PROTEIN

$5 \cdot 1 \mathrm{~g}$.

Fig. 3.-Serum electrophoresis in five cases.

admission when she had developed a sore throat and 12 days later both wrists became swollen (Fig. 4, overleaf). She had a temperature of $101^{\circ} \mathrm{F}$. and both wrists were swollen, red, and very painful.

Laboratory findings included an erythrocyte sedimentation rate of $145 \mathrm{~mm}$. in 1 hour (Westergren), a haematocrit of 32 per cent., and a white blood count of 10,500 per c.mm. with a normal differential count. The antistreptolysin-O titre was less than 200 units, Rose-Waaler titre $1: 2$, and latex fixation negative. Total protein was $7.9 \mathrm{~g}$. per cent. and electrophoresis showed a high, narrow gamma globulin peak (Fig. 3). On ultracentrifugation there was no increase in the amount of macroglobulin, but the concentration of 7S gamma globulin was greatly increased. Marrow biopsy showed 15 per cent. of plasma cells. There was no Bence Jones proteose in the urine, and estimations of blood urea, uric acid, calcium, phosphorus, and alkaline phosphatase were all normal. $X$-ray examination showed no osteolytic lesions of myelomatosis.

She was treated with soluble aspirin $80 \mathrm{gr}$. daily for the first 5 days, but as she remained ill with a temperature rising daily to $101^{\circ} \mathrm{F}$, and there was no subsidence of the arthritis in the wrists, prednisone was substituted, and this was followed by marked improvement. A synovial biopsy of the left wrist showed a histology typical of 


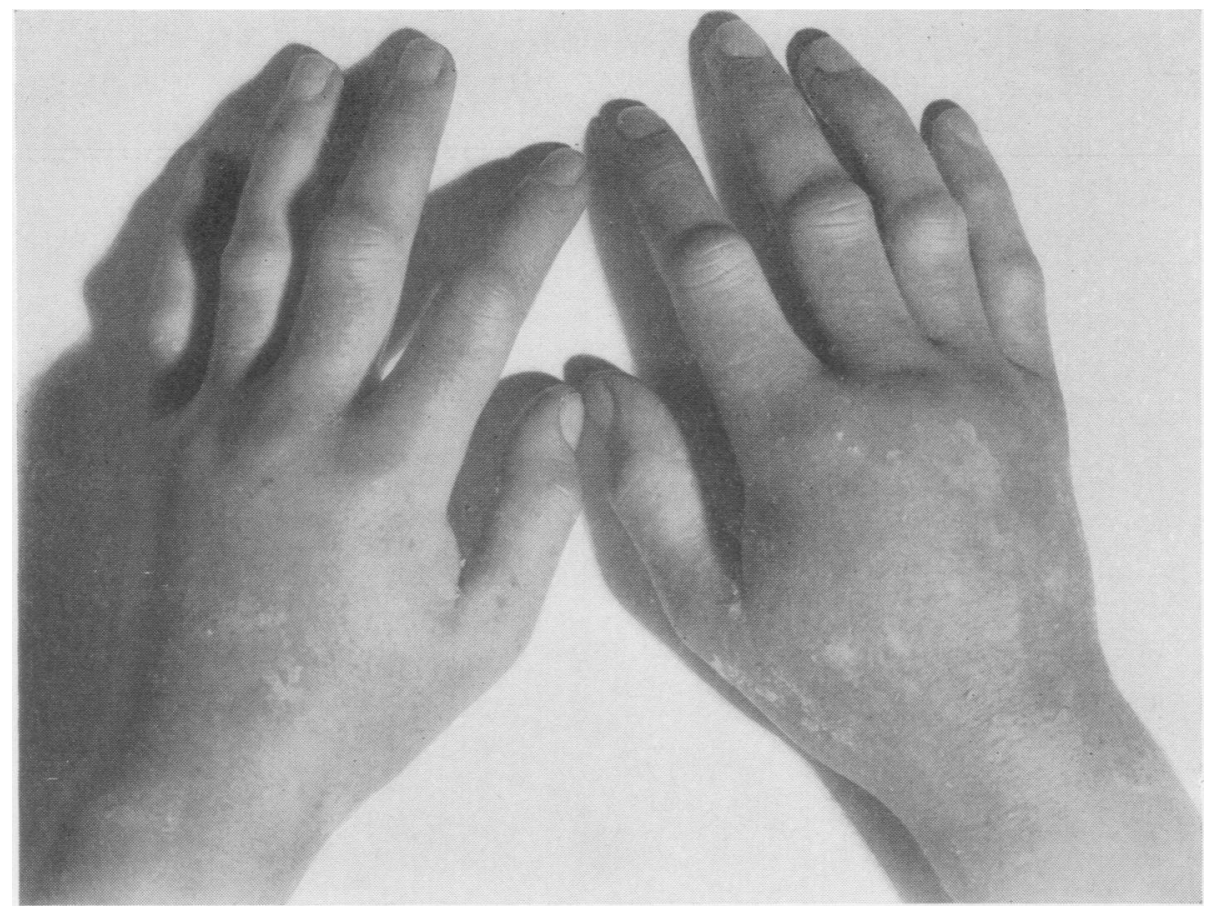

Fig. 4.-Case 4, showing acute arthritis of wrist joints.

rheumatoid arthritis (Fig. 5, opposite), and culture of the synovial membrane failed to grow organisms.

No amyloid was seen in the section and the congo red absorption was normal. Serial $x$ rays showed rapid destruction of both carpi and the wrists became ankylosed (Fig. 6, opposite).

On discharge after 4 months in hospital, she still had some pain in the wrists, but was able to resume her nursing duties. Soon after discharge the Rose-Waaler titre rose to $1: 16$. The high sedimentation rate and abnormal plasma protein pattern persisted, and in October, 1959, she was admitted to another hospital with meningococcal meningitis. She made a satisfactory recovery with intensive antibiotic therapy and was well when last seen in June, 1960.

Case 5, a 70-year-old nun, was admitted to the Canadian Red Cross Memorial Hospital in December. 1957, with severe pain in the neck. She had had chronic pain in the back, neck, and hands for 30 years, and was known to have had an erythrocyte sedimentation rate of $44 \mathrm{~mm}$. in 1 hour 3 years previously when she had a transitory lung infection. Examination showed some limitation of neck extension, bony swelling of the second and third metacarpophalangeal joints in both hands, and Heberden's nodes.

Laboratory findings included an erythrocyte sedimentation rate ranging from 17 to $33 \mathrm{~mm}$. in 1 hour, a haematocrit of 40 per cent., and a white blood count of 7,000 c.mm., with a normal differential count. Total proteins were $7 \cdot 8 \mathrm{~g}$. per cent. and electrophoresis showed an abnormal gamma globulin peak (Fig. 3). No macroglobulins were detected on ultracentrifugation.
There was a normal proportion of plasma cells in sternal marrow biopsy. Estimations of blood urea, serum calcium, phosphorus, and alkaline phosphatase and urine analysis were all normal. The Rose-Waalero titre was $1: 2$ and the latex fixation was negative. $X$ rays confirmed the presence of degenerative joint disease in the spine and hands.

Temporary improvement of symptoms followed treat-3 ment with analgesics and physiotherapy. When last seen? in 1960, she again complained of severe pain in the dorsal and cervical spine. The abnormal gamma globulin peak was still present on electrophoresis, but the urine was normal, and there were still no other laboratory? or $x$-ray evidences of myelomatosis.

Case 6, a 50-year-old housewife, developed rheumatoidi al thritis in 1949, and 3 years later was admitted to a chest 3 hospital for the treatment of pulmonary tuberculosis. At this time she had erythrocyte sedimentation rates of 135 to $140 \mathrm{~mm}$. in 1 hour, and after discharge began to suffer from frequent epistaxes, episodes of purpurao and urticaria, and Raynaud's phenomenon.

In May, 1955, she had a series of severe epistaxes necessitating blood transfusion and was re-admitted to the chest hospital with lung field changes probably 0 secondary to aspiration of blood, but as her sputum wass again positive for acid-fast bacilli, she was given a further course of antituberculous drugs. The chest condition improved, but she was persistently anaemien with a very high erythrocyte sedimentation rate, and an abnoimal serum globulin was seen to be present onw electrophoresis. She was therefore transferred to Hammersmith Hospital in February, 1956. 


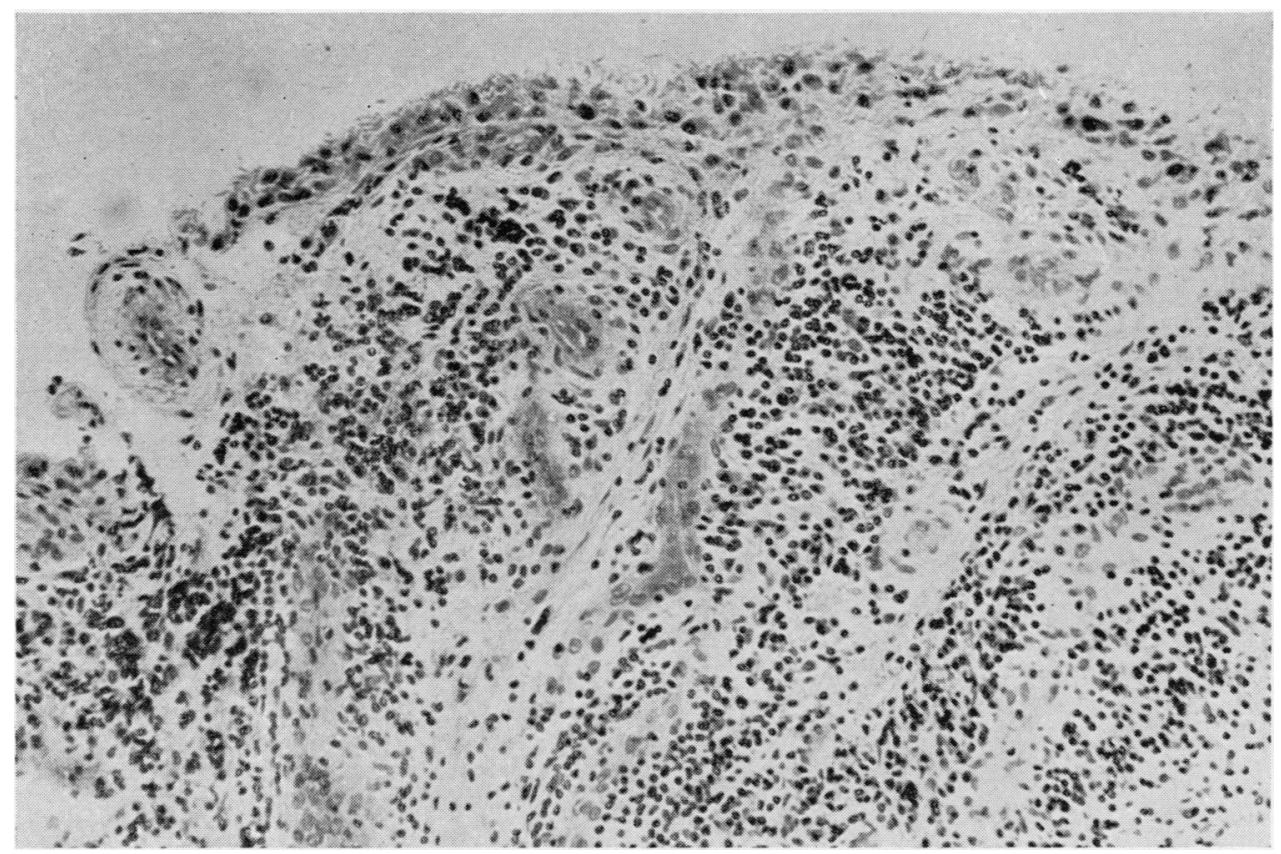

Fig. 5.-Case 4, showing biopsy of wrist joint.

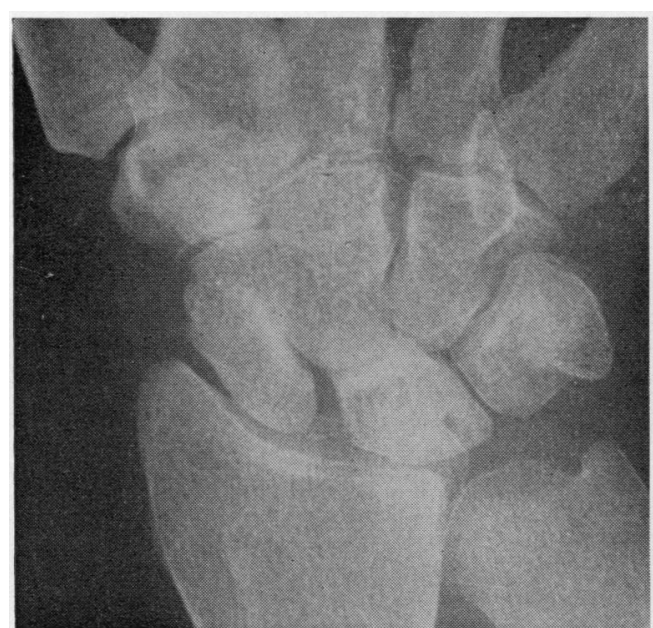

(a) December, 1957.

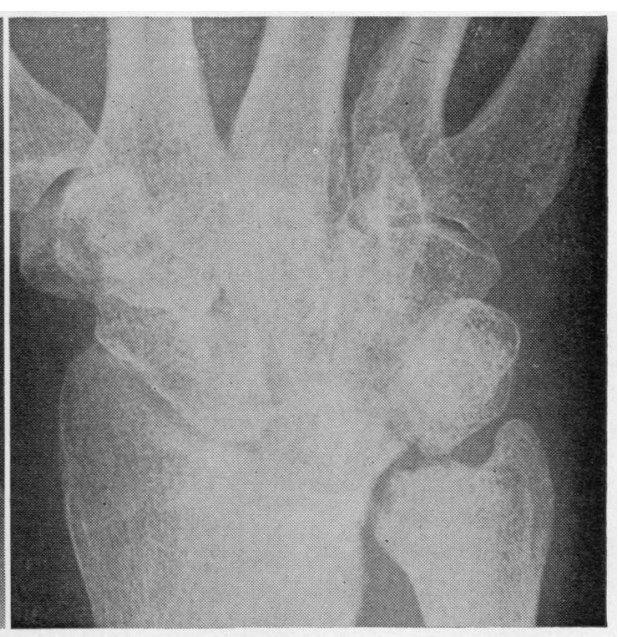

(b) July, 1958.

Fig. 6.-Case 4, showing $x$ rays of left wrist.

On examination the hands and feet showed the classical deformities of rheumatoid arthritis with subluxations and erosions, but no rheumatoid nodules. Laboratory investigations showed an erythrocyte sedimentation rate of $132 \mathrm{~mm}$. in 1 hour, a haemoglobin of $10.2 \mathrm{~g}$. per cent., and a white blood count of $4,000 \mathrm{c.mm}$., with a normal differential count. The platelet count and prothrombin time were normal, but capillary fragility was increased. The Rose-Waaler titre, latex fixation test, and examination for L.E. cells and antinuclear factor, were all negative. The total plasma proteins were $9.8 \mathrm{~g}$. per cent. with an albumin/globulin ratio of $3 \cdot 2: 6 \cdot 6$, and electrophoresis showed a high, narrow gamma globulin peak (Fig. 3). Macroglobulins were detected on ultracentrifugation and the cryocrit showed 11 per cent. cryoglobulins. Bence Jones proteose was not present in the urine, nor was there any albuminuria. The blood urea, serum calcium, phosphorus, and alkaline phosphatase were all normal. The sternal marrow biopsy contained 3 per cent. plasma cells. $X$ rays showed an 
erosive arthritis in the hands and feet, but there were no osteolytic lesions of myelomatosis.

On exposure to cold an extensive purpuric rash developed on both legs, and it was considered that most of the overt symptoms were due to cryoglobulinaemia. She was advised to avoid exposure to cold and discharged from hospital in November, 1956. Apart from occasional epistaxes she has remained well since her discharge and was last seen in October, 1960. Macroglobulins were still present, but cryoglobulins could not be detected.

Case 7, a 65-year-old housewife, was admitted to the Canadian Red Cross Memorial Hospital in October, 1959, with diarrhoea and vomiting. Since a cholecystectomy in 1946 she had had generalized rheumatoid arthritis which had run a progressive course necessitating numerous hospital admissions. She had never had systemic steroid therapy and had been maintained on salicylates apart from a few days on butazolidin 8 weeks before admission.

She was a pale emaciated woman, severely crippled by rheumatoid at thritis. There was epigastric tenderness, but no hepatomegaly or splenomegaly. Pressure sores were present on both buttocks.

Laboratory investigations showed an erythrocyte sedimentation rate of $143 \mathrm{~mm}$. in 1 houc, a haemoglobin of 6.7 g. per cent., a haematocrit of 21 per cent., and a white blood count of 2,600 per c.mm., with 2 per cent. polymorphonuclear cells. Numerous L.E. cells were present and the serum contained the antinuclear factor. The Rose-Waaler titre was $1: 256$ and the latex fixation test was strongly positive. Total protein was $8 \cdot 1 \mathrm{~g}$. per cent. with an albumin/globulin ratio of $2 \cdot 3: 5 \cdot 8$, and electrophoresis showed a high gamma globulin peak (Fig. 3). Sia's test for macroglobulins was positive. No albuminuria or Bence Jones proteose was detected, but the blood urea was $150 \mathrm{mg}$. $/ 100 \mathrm{ml}$. The Wassermann reaction and Kahn test were negative. The electrocardiogram showed changes of pericarditis, and the $x$ rays showed gross para-articular erosions of rheumatoid arthritis.

One week after admission she had a convulsion and became comatose with signs of a left hemiplegia. The following day widespread purpura appeared and she began to bleed from the gums and per rectum. She did not respond to treatment with hydrocortisone, vitamin $K$, blood transfusion, and tetracycline, and died within 48 hours. The autopsy (Dr. G. Loewi) showed changes typical of rheumatoid arthritis in the joints, pericarditis, and a haemorrhagic effusion in the large bowel. The bones were unusually soft and could be cut without undue exertion, and the marrow of the femur was largely of the red mottled variety. No evidence of myelomatosis or lupus erythematosus was found.

Case 8, a 39-year-old man, developed a septic bursitis of his left elbow after an injury in June, 1959, and later in the same month began to complain of headache, vomiting, breathlessness, and oliguria. He was admitted to the Royal Berkshire Hospital, where a diagnosis of acute nephritis was made, and because the blood urea was $210 \mathrm{mg} . / 100 \mathrm{ml}$. he was transferred to Halton Hospital for possible haemodialysis. During his stay at Halton he was dialysed four times and it was not until the 53rd day that diuresis heralded recovery. A renal biopsy had been followed by massive haematuria necessitating removal of the kidney, and the histology showed the changes of acute tubular necrosis. By 3 December, 1959 , the blood urea had fallen to $43 \mathrm{mg}$./ $100 \mathrm{ml}$. and he could concentrate to S.G. 1022 . Insw. June, 1960, his blood urea was $27 \mathrm{mg} . / 100 \mathrm{ml}$., but his urinary protein was $8 \mathrm{~g} . / 1$.

He first complained of pains in the shoulders, back and arms in April, 1960, and 2 months later he noticed soreness of the mouth and swelling of the tongue. The left knee became swollen and he had symptoms of bilateral carpal tunnel compression. Treatment with $\bar{\Phi}$ prednisone was started, with marked improvement in the pains, but the swelling of the tongue remained, andes arrangements were made for him to be admitted to $\overrightarrow{-}$ Hammersmith Hospital in September, 1960. There was. woody swelling of the tongue and floor of the mouth $\overrightarrow{\vec{H}}$ with multiple small white infiltrations inside the lowerw lip and on the buccal mucous membrane. Small nodules were also present on the conjunctiva. The heart size was normal and a firm liver edge was feltiv $2 \mathrm{~cm}$. below the right costal margin. A striking feature. was pseudohypertrophy of the muscles of the shouldert girdle contrasting with wasting of the forearms, and therew were multiple subcutaneous nodules palpable over thew shoulders and back. The movement of both wristso was limited and pressure over the carpal tunnel produced paraesthesiae in the distribution of the median nerve. There was a small effusion in the left knee joint.

Laboratory investigations showed an erythrocyte sedimentation rate of $20 \mathrm{~mm}$. in 1 hour (Westergren), and 3 a white blood count of 11,000 per c.mm. The totalo proteins were $5 \cdot 1 \mathrm{~g}$. per cent. (Fig. 3). Bence Jones proteose was present, and urinary protein was $10.2 \mathrm{~g}$. on 24 hours. The sternal marrow revealed an increase ofno plasma cells, but a skeletal $x$ ray showed no osteolyta.lesions typical of myelomatosis. The congo red cleair- $\square$ ance was 48 per cent. in 30 minutes, and a drill biopsyo of the tongue showed amyloid infiltration.

In November, 1960, the enlargement of the tongue⿳亠二口 became more marked and the mouth was ulcerated and painful. Deep $x$-ray therapy was given to the tongued in an attempt to relieve this discomfort. At the same time his heart increased in size and he developed con- $\overrightarrow{\overrightarrow{0}}$ gestive failure, and he died at home the following month.3 Autopsy confirmed the presence of widespread amyloid infiltration, and of particular interest was its presence in the synovial membrane of the left knee joint which was stained by the previous congo red. The histologicale appearance is shown in Fig. 7 (opposite).

Case 9, a 51-year-old gardener, was first seen at the Canadian Red Cross Memorial Hospital, Taplow, in 3 January, 1959, with a 6-month history of coldness and numbness of the toes and later of the fingers. He had음 also noticed weakness of the legs for several days. Until the onset of these symptoms he had been in goodo health. Examination revealed anaesthesia over the distal part of the feet and toes. The pulse rate was $132 \mathrm{~N}$ with a gallop rhythm, and all the peripheral pulses werepresent. An electrocardiogram showed changes com- $N$ patible with an old anterior infarct, with a P-R intervalin of $0.22 \mathrm{sec}$. Urine analysis was normal.

When next seen in July, 1959, he was complaining of hoarseness of the voice and difficulty in swallowing 6 and laryngoscopy revealed a smooth non-ulcerated prominence of the left false cord; a biopsy was taken, but showed no evidence of malignancy. In October; 1959 , he began to have central chest pain radiating down 


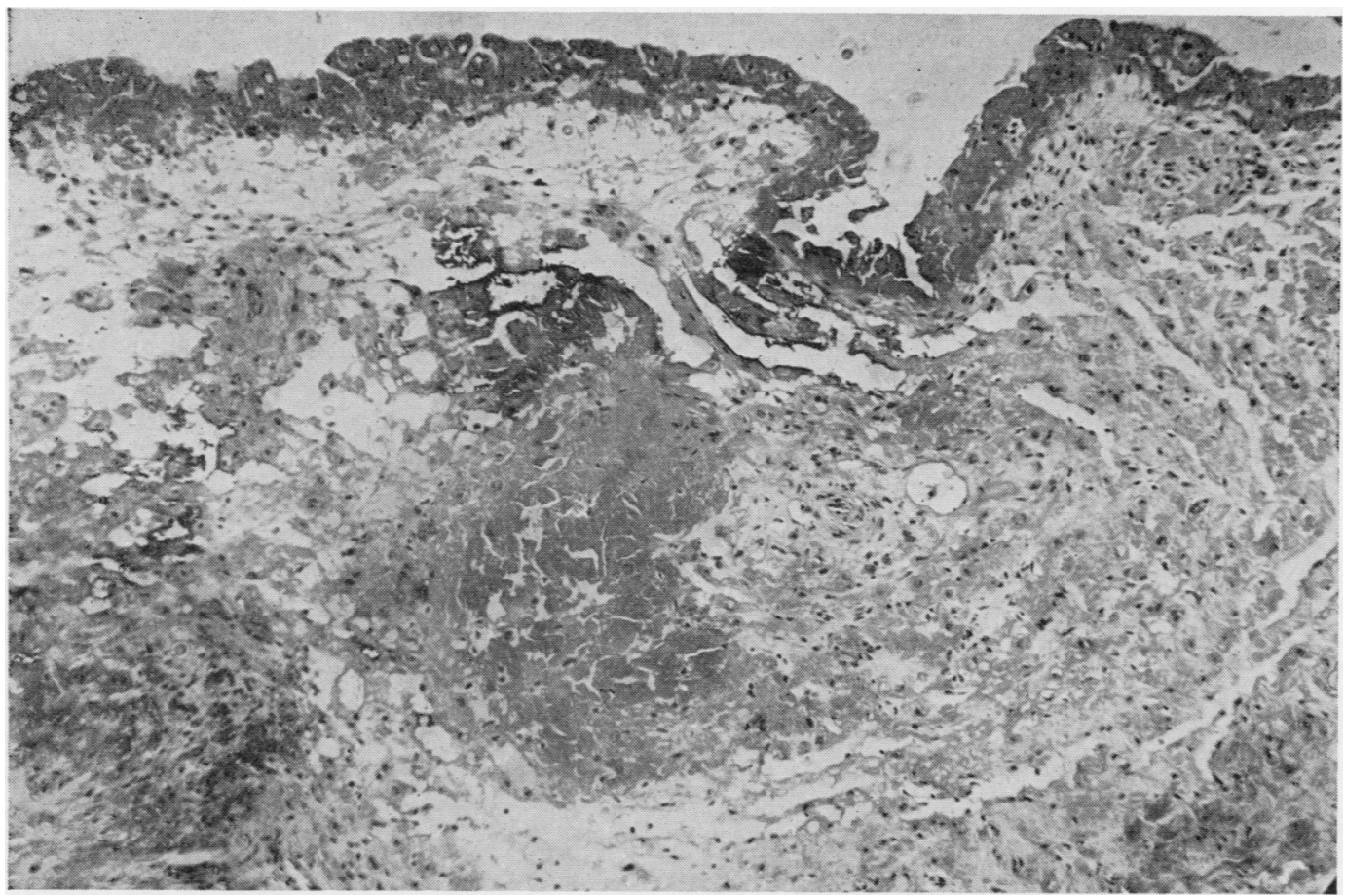

Fig. 7.-Case 8, showing autopsy section of knee joint synovium.

the left arm to the wrist; this came on when he was gardening and it was relieved by rest and trinitrin. This was followed by ankle oedema and in December, 1959, he was admitted to the Canadian Memorial Hospital with a 2-day history of diarrhoea and vomiting.

The heart was enlarged with the apex in the seventh interspace in the anterior axillary line. The jugular venous pressure was raised to the angles of the jaws, and the blood pressure was $80 / 60$. The liver was enlarged three finger breadths below the costal margin. Signs of peripheral neuritis were present in all four limbs, and he walked with a stamping gait.

Laboratory investigations showed an erythrocyte sedimentation rate of $12 \mathrm{~mm}$. in 1 hour and a haemoglobin of $12.7 \mathrm{~g}$. per cent. The serum proteins were 5.39 g. per cent., with a very low gamma globulin. The sternal marrow, Wassermann reaction, and acid and alkaline phosphatases were all normal. The possibility of primary amyloidosis was considered, and on reviewing the laryngeal biopsy it was found to contain amyloid. The patient's heart failure was temporarily controlled, but he relapsed and died in February, 1960. At autopsy (Dr. D. C. Dumonde), the presence of widespread amyloid infiltration was confirmed, affecting vessel walls, muscle fibres, skin, and myocardium.

\section{Discussion}

Amyloid deposition appears to be related in some way at present undefined with proliferation of plasma cells and increased or abnormal gamma globulin. In rheumatoid arthritis there is much proliferation of plasma cells in synovial tissue, an increased number in bone marrow, and sometimes a massive packing of the spleen. Amyloid occurs in the more severe cases. It would seem possible for a somatic mutation to occur rather more frequently in these circumstances than in normal individuals, and this might possibly be the basis for the occasional occurrence of macroglobulinaemia or myelomatosis in patients with rheumatoid arthritis. Alternatively, this could be coincidence. Another possibility is that a polyarthritis of the rheumatoid type might develop in myelomatosis, of a similar nature to that which has been reported in agammaglobulinaemia (Good, Rotstein, and Mazzitello, 1957), as there is evidence that these patients have a deficiency of normal gamma globulin. Case 4 (with arthritis of both wrists) is the only one that might fall into this category; the patient had a myeloma-like protein in the peripheral blood (Fig. 3), and joint biopsy showed changes typical of rheumatoid arthritis (Fig. 5), but it should be recalled that during the course of her illness the Rose-Waaler titre rose to $1: 16$. The two cases with long-standing rheumatoid arthritis and macroglobulinaemia would appear to come into a different category, and they emphasize that 
the finding of a high globulin peak on electrophoresis in a patient with polyarthritis may not necessarily be evidence of myelomatosis. The significance of macroglobulins in these patients is not known. It should, however, be mentioned that the presence of macroglobulins in myelomatosis has been reported (Adner, Wallenius, and Werner, 1960).

The development of gout in the course of some cases of myelomatosis is not unexpected, although the reports of its occurrence are few (Stewart and Weber, 1938; Davis, Weber, and Bartfeld, 1957). More difficult to explain is the para-amyloidosis which, as we have seen, can involve the joints and tendon sheaths. The borderland between primary amyloidosis and myelomatosis is shown in Case 8. This patient had swelling of the carpal tunnels and knee joint, and at autopsy the latter was found to be infiltrated with amyloid. Bence Jones proteose and a slight plasmacytosis of the sternal marrow were also seen, but otherwise he showed no features of myelomatosis, and all his symptoms were related to the widespread amyloid infiltration. This emphasizes the need to make a thorough search for myelomatosis in all cases of primary amyloidosis.

\section{Summary}

(1) The findings in 46 cases of myelomatosis seen at Hammersmith Hospital and the Canadian Red Cross Memorial Hospital, Taplow, during the 10 -year period from January, 1950, to January, 1960, are reviewed, and the incidence and nature of joint involvement occurring in association with this disease have been studied.

(2) Two cases of possible occult myeloma with joint symptoms, in one of which a biopsy was indistinguishable from rheumatoid arthritis, two cases of rheumatoid arthritis with macroglobulinaemia, and two cases of primary amyloidosis are also reported. The relationship between rheumatoid-like arthritis, plasma-cell infiltration, and amyloidosis is discussed.

We are grateful to Dr. A. S. McFarlane, National Institute for Medical Research, Mill Hill, for carrying out the ultracentrifuge studies, and to Dr. I. C. Gilliland, Dr. Z. L. Szur, and Dr. G. T. Thomas for allowing us to see patients under their care. We should also like to thank Prof. C. V. Harrison and Dr. D. C. Dumonde for performing the autopsies, and Mr. P. J. Fiske for preparing the illustrations.

\section{REFERENCES} Adner, P. L., Wallenius, G., and Werner, I. (1960).
Acta med. scand., 168, 431.

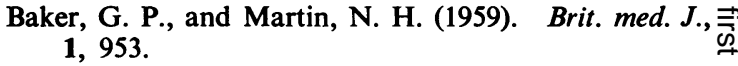

Davis, J. S., Weber, F. C., and Bartfeld, H. (1957). Ann. intern. Med., 47, 10.

Good, R. A., Rotstein, J., and Mazzitello, W. F. (1957). J. Lab. clin. Med., 49, 343.

Magnus-Levy, A. (1938). Acta med. scand., 95, 217.

Martin, N. H. (1960). Quart. J. Med., 29, 179.

Osserman, E. F. (1958). Radiology, 71, 157.

Stewart, A., and Weber, F. Parkes (1938). Med., n.s. 7, 211.

Tarr, L., and Ferris, H. W. (1939). Arch. intern. Med 64, 820 .

Symptômes articulaires dans la myélomatose et dans des affections similaires

RÉSUMÉ

(1) On passe en revue 46 cas de myélomatose observés à Hammersmith Hospital et à Canadian Red Cross Memorial Hospital, Taplow, pendant une période de dix ans, entre janvier, 1950 , et janvier, 1960 , et on étudie la fréquence et la nature de l'implication articulaire associée à cette maladie.

(2) On décrit aussi deux cas de possible myélonfę occulte avec des symptômes articulaires, dont un, hupoint de vue histologique, ne se distinguait nullement $\mathrm{e}_{\mathrm{e}}$ l'arthrite rhumatismale. De plus, on décrit deux d'arthrite rhumatismale avec macroglobulinémie et deux cas d'amyloïdose primaire. On discute le rapport entre l'arthrite du type rhumatismal, l'infiltration plasmo-مి cytaire et l'amyloïdose.

Síntomas articulares en la mielomatosis y estados similares

SUMARIO

(1) Se revisan los hallazgos en 46 casos de mielomatosiso vistos en Hammersmith Hospital y en el Canadian Red Cross Memorial Hospital, Taplow, durante el período de 10 años, comprendido entre enero de 1950 y enero de윽 1960 , y se estudia la incidencia y la naturaleza de la afectación articular asociada a esta enfermedad.

(2) Se presentan también: dos casos de posible mieloma oculto con síntomas articulares, en uno de los cuales el exámen biópsico era completamente indiferenciable del de una artritis reumatoide; dos otros casos de artritis N reumatoide con macroglobulinemia y dos más casos de amiloidosis primaria. Se discute la relación entre lan artritis del tipo reumatoide, la infiltración plasmocitaria y la amiloidosis. 